\title{
Effect of Potash on the Hearts of Rabbits
}

\author{
Ochei Kingsley Chinedum ${ }^{1}$, Omeh Yusuf Ndukaku², Obeagu Emmanuel \\ Ifeanyi ${ }^{3}$ and Obarezi Thompson Ndubuisi ${ }^{4}$ \\ 1.Department of Medical Laborator Sciences, Faculty of Basic Medicine, Ambrose Ali University Ekpoma, Edo \\ State, Nigeria. \\ 2.Department of Biochemistry, Michael Okpara University of Agriculture, Umudike, Abia State ,Nigeria. \\ 3.Diagnostic Laboratory Unit, University Health Services Department, Michael Okpara University of \\ Agriculture, Umudike, Abia State, Nigeria. \\ 4.Medical Doctor, University Health Services Department, Michael Okpara University of Agriculture, Umudike, \\ Abia State, Nigeria.
}

\begin{abstract}
Effect of potash was carried out on the hearts of rabbits. As a result of the toxicity cases that had been observed in potash intake. The study was done to determine the effect of potash on the hearts of rabbits. Twenty rabbits were used for the study. Animals were grouped into 4 (A, B, C and D). Group A served as the control while groups $B, C$, and $D$ were the treatment groups. The study revealed that continous consumption of potash resulted to some varying degrees of distortion and disruption of the cytostructure of the heart, as compared to the control group which slow normal cellular and continous consumption of potash on the heart with that of the group D appearing more remarkable.
\end{abstract}

Keywords: Potash, normal histology of rabbits and Toxicity of potash on rabbit's heart.

\section{Introduction}

From recent scientific reports, it has been discovered that there is an increased use of geological minerals in human and animal feed. Moreover, Nigeria government revitalized concern in the exploration of solid mineral could perhaps explain the reason for the use of naturally occurring inorganic substances (salts) for various purposes (Aribido et al., 2001). One of such geological mineral is potash popularly called kanwa in northern part of Nigeria. Potash is a dry lake salt and is largely a hydrated sodium carbonate (Davidson et al 1974; Oyeleke and Morton, 1981). It is a mould, growing out of the soil during rain but scrapped off, dried in the sun and sold without further treatment. In Nigeria, potash mostly occurs as a common deposit of saline lakes the deposit is usually covered by shallow water, less than two feet deep (Makanjuola and Beetlestone, 1971). Its occurrence is common in the northern part of the country, especially in Kano and Maiduguri areas, extending to border countries like Chad and Niger. According to Makanjuola and Beetlestone 1971, it is the second most commonly used salt in Nigeria. It is next important table salt and very low amounts of potassium as compared to sodium (Ekanem, 1977). There are basically varieties of potash that are well known in Nigeria and their uses have also been noted.

It has been observed by Buchanan and Purgh (1969) that potash can be administered as medicine for all sorts of ailments. As medicine, in its grounded form, it is mixed with tobacco and used as snuff. In the Northern part of Nigeria, it is also administered in large doses by the 'Hausa' majority in the form of porridge of guinea corn and millet in what is popularly called kunun Kanwa. This is administered to their women immediately after delivery as a medicine to increase the quality and quantity of breast milk (Davidson et al., 1974). Edijala (1980) determined the effects of potash on cooking time since it is commonly used by most Nigerians in the rural areas for cooking vegetables and legumes. It was observed that it increases the green colour and texture of vegetables as well as reduces the cooking time of legumes. Cowpea which is noted for its prolonged cooking time of 40-65 minutes was reduced to 10-15 minutes when cooked with a high concentration of potash. From documented literatures however, it has been observed that increased potash intake leads to decreased food and water intake in experimental animals which was followed by the presence of wrinkled skin with some hair losses (Oyeleke, 1988). More so, the toxic nature of potash was noticed in the nursing mothers around Zaria and Malunfashi areas of Northern Nigeria due to the intake of 30mg per day (Davidson et al., 1974).

\section{AIM AND OBJECTIVE}

- As a result of the toxicity cases that had been observed in potash intake, the purpose of this work is to determine the effect of potash on the heart of rabbits.

- To determine the effect of potash on the histology of the heart of rabbits. 
ANIMAL CARE

\section{Material And Methods}

The rabbits for this research were purchased from the animal house, college of medicine, Ambrose Ali University Ekpoma. Before the experiment commences, the rabbits was acclimatized for a period of one week. The rabbits were kept under standard environmental conditions such as temperature and relative humidity. All the animals was fed with with grower's mash that was purchased from Edo Feeds and Flour Mill Limited, Ewu, Edo State, Nigeria and given feeds liberally. Water will also be given to the animals under strict hygienic conditions throughout the week.

\section{PREPARATION OF POTASH BEFORE ADMINISTRATION}

The crystals of potash that were procured from general Ekpoma market were grounded into powdery form using mortar and pestle. The potash powder was mixed with the growers mash and use in feeding the rabbits except the animals in the control group that were fed with only the grower's mash and water liberally.

\section{EXPERIMENTAL DESIGN}

The twenty rabbits of relatively equal sizes and weight of $850-900 \mathrm{~g}$ were randomly assigned into four groups: A, B, C and D of five in each group. Animals in groups B, C, and D served as treatment groups while those in group A served as the control. Animals in each group were further sub-grouped. Group A was subgrouped into A1, A2, A3, A4 and A5. Group B was sub-grouped into B1, B2, B3, B4 and B5. Group C into C1, C2, C3, C4 and D5 and Group D shall sub-group into D1, D2, D3, D4 and D5. The group A animals (controls) were fed normally with growers mash while those in groups B, C, and D were administered with potash in graded dosage $(2 \mathrm{~g}, 4 \mathrm{~g}$ and $6 \mathrm{~g})$ mixed with $100 \mathrm{~g}$ of growers mash respectively. The feeds were available for the animals and were changed daily with fresh one after cleaning the containers and the animal cages.

\section{MODE POTASH ADMINISTRATION}

\section{Group 1:}

5 Rabbits were fed with $100 \mathrm{~g}$ of growers mash mixed with $2 \mathrm{~g}$ of ground potash $/ 850 \mathrm{~g}$ body weight. The feeding was performed 2 times daily for 3 weeks. Group 2:

5 Rabbits were fed with $100 \mathrm{~g}$ of growers mash mixed with $4 \mathrm{~g}$ of ground potash $/ 850 \mathrm{~g}$ body weight. The feeding was performed 2 times daily for 3 weeks. Group 3:

5 Rabbits were fed with $100 \mathrm{~g}$ of growers mash mixed with $6 \mathrm{~g}$ of ground potash $/ 850 \mathrm{~g}$ body weight. The feeding was performed 2 times daily for 3 weeks.

\section{Group 4 (control):}

5 Rabbits (control) were fed with growers mash $100 \mathrm{~g} / 850 \mathrm{~g}$ body weight. Feeding was performed 2 times daily for 3 weeks

\section{SAMPLE COLLECTION AND HISTOLOGICAL STUDIES}

The rabbits were sacrificed by cervical dislocation on the third week of the experiment. The thoracic and abdominal regions were quickly opened and the hearts dissected out and fixed in $10 \%$ formal saline for routine histological techniques.

\section{TISSUE PROCESSING AND SECTIONING}

The tissues were processed with 18 hours automatic tissue processor (LEICA TP 1020) as follows:

Beaker $110 \%$ formal saline 1 hour $30 \mathrm{mins}$

Beaker $270 \%$ alcohol 1 hour

Beaker $380 \%$ alcohol 1hour

Beaker $490 \%$ alcohol 1 hour

Beaker $595 \%$ alcohol 1 hour

Beaker $695 \%$ alcohol 1 hour 30minutes

Beaker 7 absolute alcohol I 2hours

Beaker 8 absolute alcohol II 2hours

Beaker 9 xylene I 1hour 30minutes

Beaker $10 \quad x y l e n e$ II 1hour 30minutes

Wax bath I 2hours

Wax bath II 2hours. As in use in (OAUTHC, Ile-Ife)

After the last timing, the tissues were removed from their plastic cassettes and placed at the centre of the metallic tissue mould and then filled with molten paraffin wax. They were also left to solidify after which they were now placed in the refrigerator at $5^{\circ} \mathrm{C}$ for 15 minutes. After the blocks were cool in the refrigerator for the time stated above (15 minutes), the blocks were then removed from the metallic case using a knife and after which the paraffin wax at the side of the blocks were removed.

The blocks were then trimmed and cut serially at $3 \mu \mathrm{m}$ on a rotary microtome. The sections 
were floated in water bath at $55^{\circ} \mathrm{C}$ and picked up by the use of a clean frosted end slides. The frosted end slides were now placed on the hot plate for 40 minutes for adequate attachment of the sections on the slides after which the sections were de-waxed, hydrated, air dried and stored in a slide box ready for staining process.

\section{HAEMATOXYLIN AND EOSIN STAINING PROCEDURE}

Sections for general tissue structure were stained by Haematoxylin and Eosin technique.

1. The sections were dewaxed in 3 changes of xylene 5 minutes

2. The sections were hydrated through descending grades of alcohol (absolute, $95 \%, 80 \%$ and $70 \%$ ).

3. The sections were stained in Harris haematoxylin 5 minutes

4. The sections were rinsed in running tap-water to remove excess stain

5. The sections were differentiated in $1 \%$ acid alcohol 3 seconds

6. The sections were blued in running tap water 10 minutes

7. The sections were counterstained with $1 \%$ eosin 1 minute

8. Sections were finally rinsed in water, dehydrated in ascending grades of alcohol $(70 \%, 80,95 \%$ and absolute)

9. The sections were cleared in xylene, air-dried and mounted with dibuthylphthalate propylene xylene (DPX). As in use in (OAUTHC Ile-Ife) The slides were examined under a light microscope and photomicrographs were taken.

\section{CONTROL}

\section{Results}

\section{GROUP A}

Control heart sections showed a fairly preserved heart muscle coloured with haematoxylin plus eosin that demonstrated general heart muscle myocytes. There are intracavity red blood cells well preserved.

\section{Test Group B}

There are clear spaces between strands of cardiac muscle layers. Myocytes, cytoplasm and nuclei are well preserved and stained with haematoxylin and Eosin. Pericardial muscles are also well preserved.

\section{Test Group C}

Heart muscle section showed a congested myocardial tissue infiltrated with red blood cells. The heart muscle appeared preserved with no appearance of clear space and myocytes were well demonstrated. Pericardial muscle is poorly preserved.

\section{Test group D}

Heart muscle section showed more prominent congestion with expanded blood vessels filled with red blood cells that are well preserved. Clear spaces appear more prominent with tattered myocardial strands.

Table 1.0: Histological Observations Of The Effect Of Potash On The Heart Of Rabbits.

\begin{tabular}{|c|c|c|c|c|c|c|c|c|c|c|c|c|c|c|c|c|c|c|c|}
\hline \multirow{2}{*}{$\begin{array}{l}\text { HISTOLOG } \\
\text { ICAL } \\
\text { OBSERVAT } \\
\text { ION } \\
\end{array}$} & \multicolumn{4}{|c|}{$\begin{array}{c}\text { GROUP A } \\
\text { (CONTROL } \\
\text { ) }\end{array}$} & \multicolumn{5}{|c|}{$\begin{array}{c}\text { GROUP B } \\
\{\text { TEST }(\mathbf{3 g})\}\end{array}$} & \multicolumn{5}{|c|}{$\begin{array}{c}\text { GROUP C } \\
\{\text { TEST }(6 \mathbf{g})\}\end{array}$} & \multicolumn{5}{|c|}{$\begin{array}{c}\text { GROUP D } \\
\{\text { TEST }(9 \mathrm{~g})\}\end{array}$} \\
\hline & \begin{tabular}{|l|l}
1 & \\
\end{tabular} & $\begin{array}{l}3 \\
\end{array}$ & 4 & 5 & 1 & 2 & 3 & 4 & 5 & 1 & 2 & 3 & 4 & 5 & 1 & 2 & 3 & 4 & 5 \\
\hline $\begin{array}{l}\text { Clear space } \\
\text { in between } \\
\text { muscle } \\
\text { strands }\end{array}$ & & & & & + & + & + & + & + & - & - & - & - & - & ++ & ++ & ++ & ++ & ++ \\
\hline $\begin{array}{l}\text { Consgested } \\
\text { myocardial } \\
\text { tissues }\end{array}$ & & & & & - & - & - & - & - & + & + & + & + & + & ++ & ++ & ++ & ++ & ++ \\
\hline $\begin{array}{l}\text { Red blood } \\
\text { cells } \\
\text { infilteration }\end{array}$ & & & & & - & - & - & - & - & + & + & + & + & + & + & + & + & + & + \\
\hline $\begin{array}{l}\text { Intilteration } \\
\text { Expanded } \\
\text { blood vessels }\end{array}$ & & & & & - & - & - & - & - & - & - & - & - & - & + & + & + & + & + \\
\hline $\begin{array}{l}\text { Tattered } \\
\text { myocardial } \\
\text { strands }\end{array}$ & & & & & - & - & - & - & - & - & - & - & - & - & + & + & + & + & + \\
\hline
\end{tabular}

KEY:

- = Negative.

$+=$ Mild positive. $++=$ Moderate. 


\section{PHOTOMICROGRAPHY (HISTOLOGICAL OBSERVATION)}

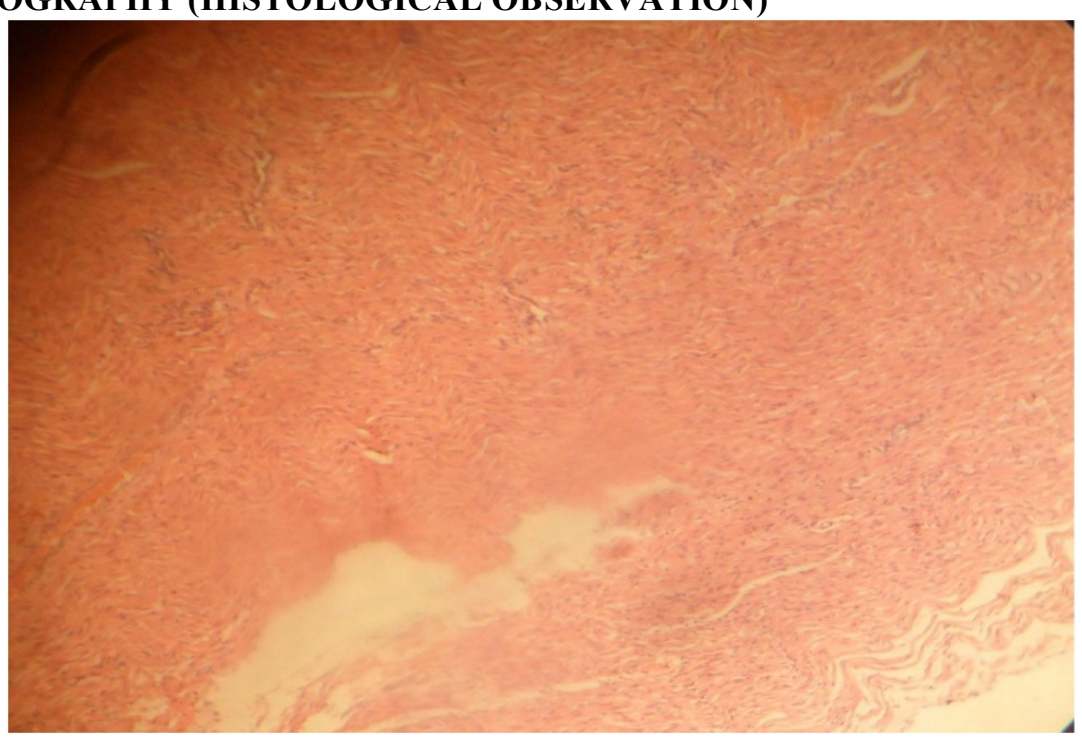

Figure 1: $(\mathrm{H}+\mathrm{E}$ x 400) Control heart section (A2) showing fairly preserved heart (cardiac) muscles as well as the myocytes.

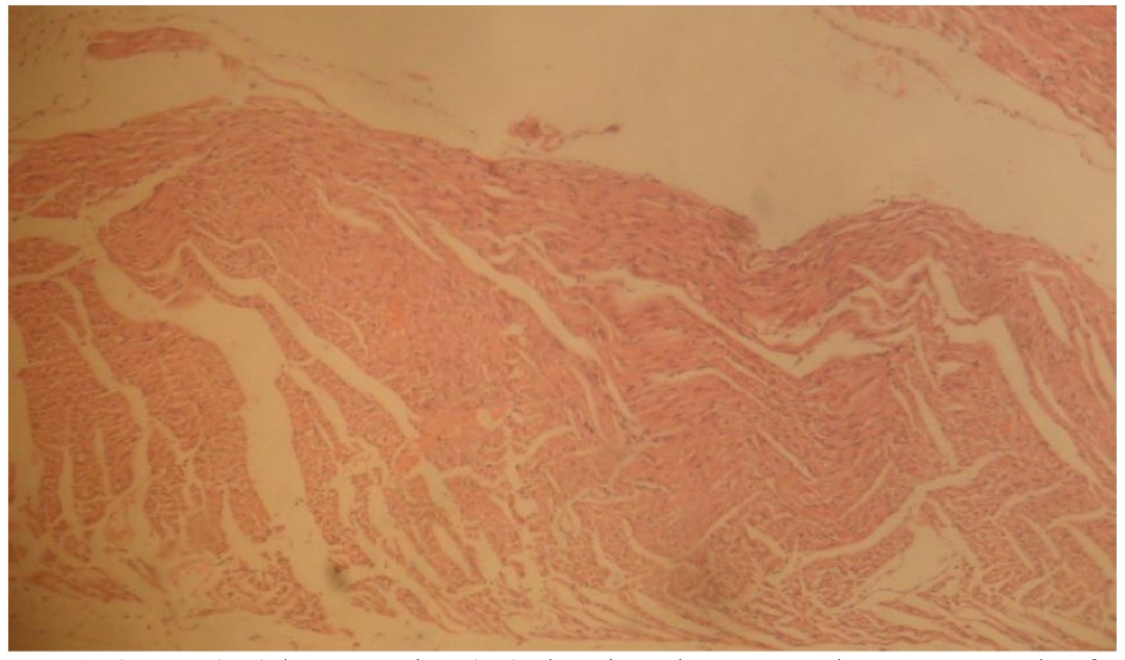

Figure 2: $(\mathrm{H}+\mathrm{E} \mathrm{x} 400)$ Test (B2) heart section (2g) showing clear spaces between strands of cardiac muscles layers. Myocytes, cytoplasm, nuclei and pericardial muscles are well preserved.

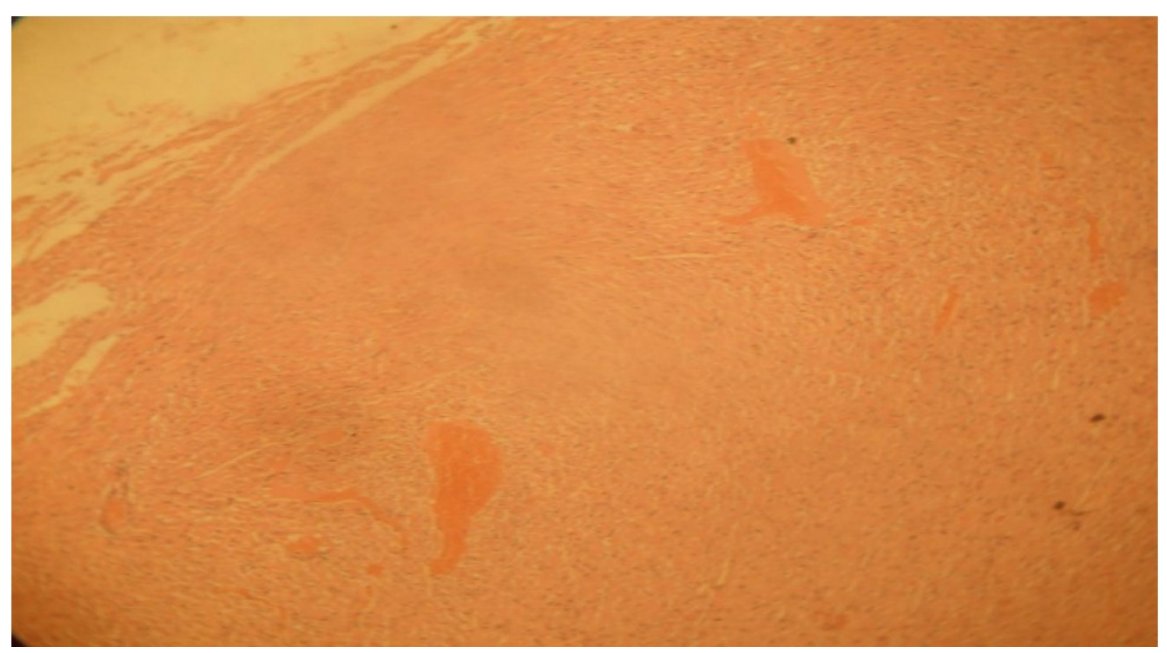

Figure 3: $(\mathrm{H}+\mathrm{E} \times 400)$ Test $(\mathrm{C} 5)$ heart section (4g) showing congested myocardial tissues infiltrated with red blood cells, well preserved myocytes, heart muscles and poorly preserved pericardial muscles. 


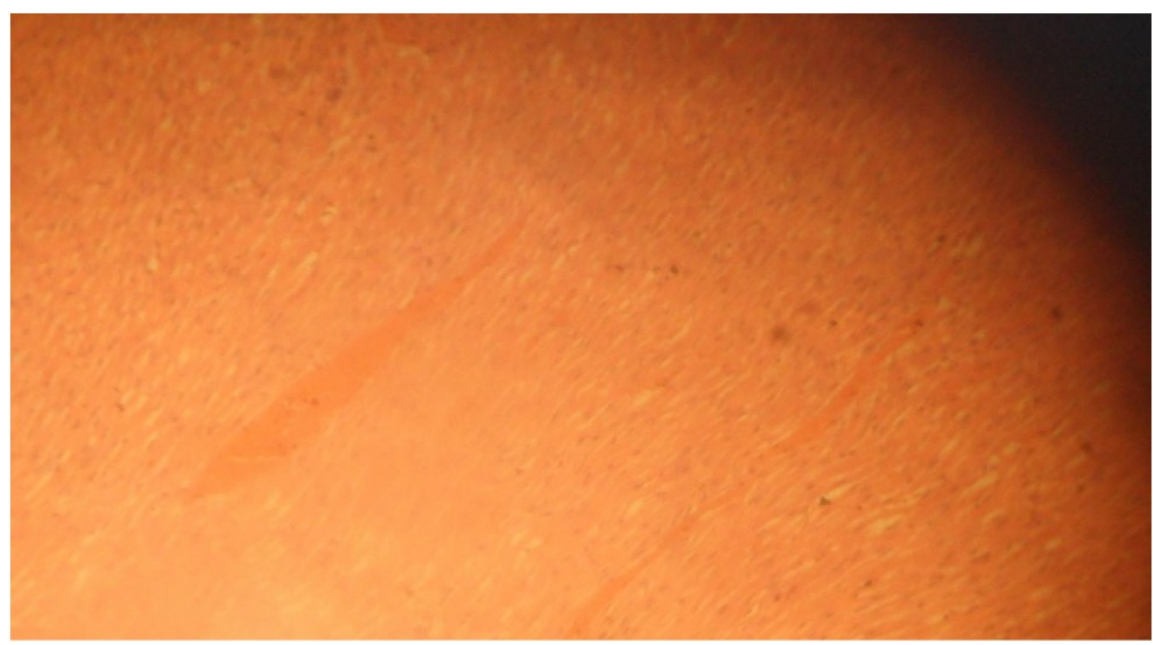

Figure 4: $(\mathrm{H}+\mathrm{E} x 400)$ Test (D2) heart section (6g) showing more prominent congestion with expanded blood vessel filled with red blood cells, well preserved intra heart muscle strands as well as more prominent clear spaces with tattered myocardial strands.

\section{Discussion}

The study revealed that continuous consumption of potash (kanwa) resulted to some varying degree of distortion and disruption of the cytostructure of the heart, as compared to the control group which show normal cellular and architectural integrity. The result obtained in this experiment is probably due to the continuous consumption of potash (kanwa) on the heart with that of the group D appearing more remarkable. It demonstrates that potash (kanwa) consumption may not be as harmless as generally believed. The structural changes in the heart observed in this experiment could be associated with functional changes that may be detrimental to the health status of the animals. Although the actual mechanism by which potash induced cellular degeneration observed in this experiment is unknown and needs further investigation.

\section{Conclusion}

The aim of using potash on experimental rats was to determine the effects of its repeated use on heart tissues as it is one of the major food supplement in most rural areas in Nigeria and other parts of West African countries. Considering the observations in the results of this experiment, it is obvious that in everyconcentration of the administered potash caused considerable histological abnormalities and cytostructural distortion of the heart, which may be linked to the cytotoxic effects of potash (kanwa) on the heart tissues. If can also be inferred from the results of this experiment that the distortion of the cytoarchitecture of the heart tissues is associated with functional changes that may have been detrimental to the health status of the animals as a result of potash interference on the heart tissues.

However, it has been reported that the extent of severity of tissue damage of a particular compound as toxicant depends on its toxic potentiality on the tissues of organisms. More so, susceptibility to chemical injury varies greatly in the tissues and cells of the same animal. It is sometimes greater in different animal groups. In addition, the location of the major damage may be determined by the mode of action of the chemical. The mode of action of each poison and the pattern of tissue vulnerability has been well defined and the toxic level of each agent at which a fairly standard distinctive pattern of tissue damage has been studied. The result also showed that potash acted as cytotoxic substance to the heart tissues due to its degenerative effects which were seen even at the lowest concentration. The level of potash consumed in various homes however may not be toxic if not takencontinuously taken as indicated that the effects of potash to the heart tissues are dosage or concentration dependent.

\section{Recommendation}

The injurious effect of potash due to its continuous use in various homes can be avoided by discouraging excessive use as its accumulation could cause serious damage to body organs. More research to ascertain the amount that safe for consumption should be carried out.

\section{References}

[1]. Ankrah, E.K and Dovio, F.E. (1978): The properties of Trona and its effect on the cooking time of cowpeas. J. Sci Food Agri; 29: Pp. 950952.

[2]. Aribido, S.O, Ogunmodede, B.K and Lakpini, C.A.M (2001): nutritional assessment of 'Gwanwarasa' Type of Natural Potash (Kanwa). Nigerian Journal of Chemical Research, vol. 6 (3); Pp. 27-30. 
[3]. Awvioro, O.G (2010): Histochemistry and Tissue Pathology: Principles and Techniques (second edition): Theory of Staining. University Press, Delta State University, Abraka, Nigeria. ISBN: 978-35627-9-7. Pp. 113-126.

[4]. Bateman, A.M (1991): The formation of mineral deposits, John Wiley Publ.Co., New York, $2^{\text {nd }}$ ed. Pp. 194.

[5]. Behrman, R.E., Kliegman, R.M. and Jenson, H.B. (2000): Nelson Textbook of Pediatrics, 16th ed. Philadelphia, Saunders. Pp. 31 2-31 9 .

[6]. Buchanan, K.M and Purgh, J.C (1961): Land and People in Nigeria, $7^{\text {th }}$ Imp. London, University of London Press. Pp. 44-62.

[7]. Campbell D. (1997): Reece biology. Human body and health. $7^{\text {th }}$ Ed. Pp. 873-874

[8]. Cecie, S., Christine, E. and Lisa, S. (2009): Biology. Today and tomorrow with physiology. Cengage Learning. Pp. 422-430. ISBN: 978-0-495-56157-6. Retrieved 7 June 2012.

[9]. Dean, D.X. and Herbener, T.E. (2000): Cross-Sectional Human Anatomy, Lippincott Williams \& Wilkins. Pp. $452-457$.

[10]. Guyton, A.C and Hall, J.E. (2006): Textbook of medical physiology (11 ${ }^{\text {th }}$ ed). Philadelphia: Elsevier Saunder. ISBN: 0-7216-0240-1.

[11]. Pratiyogita, D. (2012): Competition science vision. Pp. 55. Retrieved 7 June 2012

[12]. Davidson, N.M., Trevitt, L. and Parry, E.H.O. (1974): Peripartum cardiac failure and explanation of the observed geographical distribution in Nigeria. Bulletin WHO; 51: Pp. 203.

[13]. Davidson, N.M., Trevitt, L and Parry E.H.O. (1974): Peripartum Cardiac Failure. Cardiovascular Disease in Tropics. London, British Medical Association. Pp. 37: Pp. 1251.

[14]. DuBose, T.J., Cunyus, J.A. and Johnson, L. (1990): Embryonic Heart Rate and Age. J. Diagn Med. Sonography. 6 (3):151-157.

[15]. DuBose, T.J. (1996): Fetal Sonography. Philadelphia: WB Saunders. ISBN: 0- 7216-05432-0. Pp. 263-274.

[16]. Ekanem, E.J (1977): A preliminary analysis of samples of Kanwa for sodium, potassium and other minerals. J. Biochemical Analysis; 2(1): Pp. 25 - 43.

[17]. Eweka A.O, (2007): Histological studies of the effects of monosodium glutamate on the kidney of adult Wister rats. The Internet Journal of Health. Volume 6 (2): Pp. 2.

[18]. Eweka, A.O, and Om'Iniabohs F.A.E. (2008): Histological studies of the effects of monosodium glutamate on the lateral geniculate body of adult wistar rats. Internet J. Nutr. Wellness; 5(1). Pp. 10 - 14.

[19]. Fage, S. (1982): The natural history of aortic stenosis in adults. Am Heart J; 99: 419-424.

[20]. Gefu I., O'Rourke, R.A. and Braunwald, E. (1998): Physical examination of the cardiovascular system. In: Principles of Internal Medicine. New York, NY: McGraw-Hill: 1231-7.

[21]. Georges-Ivo, Ekosse (2010): African Journal of Biotechnology. X-ray diffraction study of kanwa used as active ingredient in achu soup in Cameroon. Vol. 9(46):Pp.7928-7929.ISSN :1684-5315. http://www.academicjournals.org/AJB: Retrieved 15th November, 2010 .

[22]. Ger, O., Braunwald, E. and Perloff, J.K. (1996): Physical examination of the heart andcirculation. In: Zipes DP, Libby P, Bonow RO, Braunwald E, editors. Braunwald's Heart Disease: A Textbook of Cardiovascular Medicine. 7th edition. Philadelphia, PA: Elsevier: 77.

[23]. ICDD, International Centre for Diffraction Data (2001): International Centre for Diffraction Data. Mineral Powder Diffraction File Data book: Pp. 942.

[24]. Ikwuegbu, O.A., Gbodi, T.A., and Umo, I. (1984): Proc. Nat. Conj on Disease of Ruminants. NURI; VOM, Pp. $103-120$.

[25]. Iwunze, M.O. (1988): A preliminary analysis of the constituents of the Nigerian crude potash. Nig J. Sci. Tech.; 4: Pp. 64-70.

[26]. JAB, Journal of Applied Biosciences (2008): Starch modification potential of kanwa, an alkaline salt.Vol.7: ISSN: 1997-5902: Pp. 191 194. http://www.biosciences.elewa.org

[27]. MacDonald, M. (2009): Your body. The Missing Manual. Sebastopol, CA: Pogue Press. ISBN: 0-596-80174-2.

[28]. Makanjoula, A.A and Beetlestone J.G (1975): Some Chemical and Mineralogical notes on Kaun. J. Min. Geolo. 10: Pp. 1-2.

[29]. Makanjuola, A.A and Beetlestone, J.G (1975): Some chemical mineralogical notes on Kaun (Trona). J. Mining and Geology; 10 (1\&2); Pp. 31-41.

[30]. Marieb, Elaine Nicpon (2003): human medical anatomy and physiology. $6^{\text {th }}$ ed. Upper Saddle River: Pearson Education.

[31]. Medical Dictionary. www.thefreemedicalditionary.com. Retrieved 2011-05-10 MedicaLook, 2010: Heart. www.medicalook.com

[32]. Michel, P.L., Iung, B. and Abou, J.S. (1995): The effect of left ventricular systolic function on long term survival in mitral and aortic regurgitation. J Heart Valve Dis;4 Suppl 2:S160-8.

[33]. Oyeleke, O.A and Morton, I.A (1981): Improvement of lysine availability from cowpeas cooked with 'Kanwa'. Nig. J. Nutri. Sci. 1: Pp. $2-123$.

[34]. Oyeleke, O.A. (1988): Effects of consumption of "kanwa" in food and water on certain physiological states of rats. Nig. J. Nutri. Sci; 4: Pp. $137-140$

[35]. Pearson, E. (2010): Emergency Medical Responder. $3^{\text {rd }}$ Can Ed. Pearson. Pp.131.

[36]. Romer Alfred Sherwood and Parsons, Thomas S. (1977): The Vertebrate Body. Philadelphia, PA: Holt-Saunders International. ISBN: 0-03-91 0284-X. Pp. 437-442.

[37]. Sanderson, E., Shaver, J.A. and Salerni, R. (2000): Auscultation of the heart. In: The Heart. New York, NY: McGraw-Hill: 253314.

[38]. Sibanda, S and Said (1991): AN NLPD/ACJAR Forage production and utilization Workshop, Zaria.

[39]. Slaby, F.J., McCune, S.K. and summers, R.W. (1994): Gross Anatomy in the Practice of Medicine. Philadelphia: Lea \& Febiger. Pp. 315-330.

[40]. Sodipo, O.A, Akpan, A.E, Ajayi, 0.0 and Akanji, M.A (1992): Effect of normal consumption of Trona ("Kanwa") - a local mineral salt lick and human erythrocytes-I. In: Abstracts from the 5th International Chemistry Conference in Africa, Gaborone, Botswana; July: 36.

[41]. Sodipo, O.A, Akpan, A.E, Ajayi, 0.0 and Akanji, M.A (1992): Normal consumption of Trona ('Kanwa') - a local mineral salt lick and human healthIl. In: Abstracts from the $5^{\text {th }}$ International Chemistry Conference in Africa, Gaborone, Botswana; August: 37.

[42]. Swartz, M .H. (2002): Textbook of Physical Diagnosis, History and Examination, 4th ed. Philadelphia, Saunders.

[43]. Torrent-Guasp, F., Buckberg, G.D., Clemente, C., Cox, J.L., Coghlan, H.C. and Gharib, M. (2001): The structure and function of the helical heart and its buttress wrapping. I. The normal macroscopic structure of the heart. Semin Thoracic Cardiovasc Surg 13:301-31 9.

[44]. Turner, F.M (1989): The Condensed Chemical Dictionary. London, England: Chapman and Hall Ltd; Pp. 1177.

[45]. Uzogara, S. G, Morton, I. D and Daniel, J. W (1988): Quality changes and mineral content of cowpea (Vignia unguiculata L. Warp) seeds processed with kanwa alkaline salt. J. Food Chem. 30 (2): Pp. 1-18.

[46]. Wikipedia (2010): Information on the heart and heart function. http//www. indexedvisuals. com/scripts/i vstock/pic. Asp. Retrieved $12^{\text {th }}$ June, 2011. 